\title{
УДК 377.114.01
}

Клокар Наталія Іванівна, кандидат педагогічних наук, доцент, ректор Київського обласного інституту післядипломної освіти педагогічних кадрів, м. Біла Церква

\section{ОРГАНІЗАЦЙНО-ПЕДАГОГІЧНІ ЗАСАДИ СТВОРЕННЯ ЕЛЕКТРОННИХ НАВЧАЛЬНО-МЕТОДИЧНИХ КОМПЛЕКСІВ ДЛЯ УЧНІВ}

\author{
Анотація
}

У статті висвітлено дидактичні засади створення електронних навчальнометодичних комплексів для учнів. Визначено компоненти, характерні ознаки, загальні і специфічні принципи їх створення, типи ЕНМК за характером організації взаємодії, за видами (гіпермедійний для on-line використання; мультимедійний для розміщення на компакт-диску або інших електронних носіях). Описано повний управлінський цикл створення електронних навчально-методичних комплексів для обдарованих учнів. Проаналізовано компоненти змістової складової, інформаційно-технологічні вимоги до створення та використання ЕНМК.

Ключові слова: електронний навчально-методичний комплекс, інформаційноосвітній ресурс, загальні і специфічні принципи створення ЕНМК, компоненти змістової складової ЕНМК, інформаційно-технологічні вимоги до створення та використання ЕНМК.

На сучасному етапі розвитку освіти дистанційне навчання розглядається як індивідуалізований процес передання та засвоєння знань, умінь, навичок і способів пізнавальної діяльності особистості, який відбувається за опосередкованої взаємодії віддалених один від одного учасників навчання у спеціалізованому середовищі, яке створене на основі використання сучасних психолого-педагогічних та інформаційнокомунікаційних технологій.

На сьогодні вчитель перестав бути єдиним джерелом інформації. Споживачі освітніх послуг, а особливо - обдарована учнівська молодь, прагнуть до засвоєння нових знань, не обмежуючись лише заняттями за розкладом та наявною в закладі освіти навчальною літературою. У зв’язку з цим посилюється інтерес учнів до інформаційних та освітніх ресурсів, у тому числі - до дистанційного навчання. 
Зростає роль регіональних закладів післядипломної педагогічної освіти, які покликані здійснювати науково-методичний супровід та прогнозування професійного розвитку педагогічних працівників в умовах постійного оновлення інформації і вимог суспільства до конкурентоздатної особистості.

Одним із пріоритетних завдань регіональних закладів ППО є пошук та підтримка творчо працюючих педагогів, які здатні оперативно розв’язувати освітні завдання в умовах зміни соціально-економічної й освітньої політики, впроваджувати інноваційні технології й сучасні методики навчання і виявляти високий рівень творчої активності та професійного саморозвитку.

Особливий інтерес нині викликає питання використання інформаційнокомунікаційних технологій у навчально-виховному процесі, зокрема - електронних підручників, посібників, Інтернет-ресурсів. 3 метою підтримки і творчого розвитку обдарованих дітей і молоді у контексті завдань проекту «Обдарована дитина» Програми розвитку системи освіти Київської області на 2008-2012 роки, Київської обласної очно-заочної школи для обдарованих учнів «Інтелектуал» групою науковців, методистів і провідних педагогів області обгрунтовано ідею створення електронних навчально-методичних комплексів (далі - ЕНМК) з навчальних предметів.

Базою для проведення такої роботи є досвід науково-педагогічних працівників Київського обласного інституту післядипломної освіти педагогічних кадрів (далі КОІПОПК), набутий у процесі створення програмно-методичних комплексів освітньої діяльності курсів підвищення кваліфікації педагогічних працівників за дистанційною формою навчання. Такі комплекси підготовлено із 39 спеціальностей, що дає можливість організувати i проводити підвищення кваліфікації за дистанційною формою навчання для усіх бажаючих педагогів закладів освіти Київської області й України.

Електронний науково-методичний посібник «Програмно-методичні комплекси освітньої діяльності курсів підвищення кваліфікації педагогічних працівників за дистанційною формою навчання», підготовлений авторським колективом під керівництвом Н. І. Клокар, розглянуто і схвалено Інститутом інноваційних технологій i змісту освіти МОН України до використання в закладах післядипломної педагогічної освіти України. 
На нашу думку, досвід створення програмно-методичних комплексів ПК за дистанційною формою навчання слугує розробленню ЕНМК для учнів, сприяє забезпеченню пріоритетності навчання, виховання i підтримки обдарованих дітей як важливого чинника формування умов для становлення особистості, збереження i розвитку інтелектуального потенціалу нації, зростанню якості підготовки обдарованої учнівської молоді до участі у творчих конкурсах, турнірах, олімпіадах, забезпечує доступ учням, особливо сільської місцевості, до інформаційно-освітніх ресурсів, об'єднує зусилля навчальних закладів, наукових установ і сім’ї у створенні сприятливих умов для розвитку та творчої самореалізації обдарованих учнів, а також навчання дітей 3 особливими освітніми потребами.

3 цією метою розроблено Концепцію та Положення створення ЕНМК для учнів, що схвалені колегією головного управління освіти і науки Київської обласної державної адміністрації. Концепція $є$ нормативним документом діяльності творчих груп педагогічних працівників, які працюють над розробленням комплексів, у якій висвітлено дидактичні основи створення ЕНМК для учнів, визначено компоненти, характерні ознаки, типи ЕНМК, загальні і специфічні принципи їх створення. Охарактеризовано компоненти змістової складової, інформаційно-технологічні вимоги до створення та використання таких комплексів.

В основі створення ЕНМК - використання сучасних педагогічних, інформаційних i телекомунікаційних технологій. Такий підхід забезпечує оптимальний доступ до якісної освіти всім учасникам навчально-виховного процесу незалежно від місця проживання, стану здоров'я і соціального статусу, реалізацію особистісно орієнтованого й діяльнісного підходів; сприяє диференціації й індивідуалізації навчання; формує інформаційну мобільність і високий рівень самоорганізації, інформаційну компетентність суб'єктів навчання.

До організаційно-педагогічних умов створення ЕНМК відносимо діяльність творчих груп педагогічних працівників за фахами, які працюють на базі КОІПОПК. Метою створення таких комплексів $є$ забезпечення всім учням, у тому числі обдарованим і дітям з особливими освітніми потребами, відкритого доступу до освітньо-інформаційних ресурсів на основі використання сучасних педагогічних, інформаційних і телекомунікаційних технологій.

Досягнення визначеної мети передбачає реалізацію таких завдань: 
1. Формування творчих груп для створення ЕНМК для учнів зі складу науковців, методистів і педагогічних працівників, які володіють IКТ і є визнаними майстрами 3 предмета.

2. Науково-методичне консультування педагогічних працівників закладів освіти регіону 3 розроблення ЕНМК.

3. Створення ЕНМК.

4. Управління роботою творчих груп зі створення ЕНМК для учнів.

5. Використання створених ЕНМК у навчально-виховному процесі, в тому числі для підготовки обдарованих учнів до участі у творчих конкурсах, турнірах, олімпіадах, дітей з особливими освітніми потребами для організації навчання на дому за індивідуальними програмами тощо.

6. Моніторингове дослідження результативності використання ЕНМК в освітньому процесі регіону.

Електронний навчально-методичний комплекс розуміється нами як інформаційно-освітній ресурс, у якому пропонується настанова користувачеві, висвітлюється зміст навчального курсу, пропонується комплекс тестових i практичних завдань, тренувальних вправ, лабораторних, контрольних i залікових робіт, рекомендацій для самооцінювання і саморозвитку.

Вивчення наукових джерел та досвід розроблення й використання ЕНМК у навчально-виховному процесі i курсах ПК педагогічних працівників підтвердив правильність обраних нами підходів до визначення його компонентів, як-от: 1) анотація; 2) програма курсу і тематичний план; 3) навчальний посібник для учнів (у формі інтерактивної комп’ютерної програми; Інтернет-ресурсу); 4) робочий зошит; 5) завдання для самостійної роботи учнів; 6) наочні матеріали; 7) глосарій; 8) список літератури, Інтернет-ресурси; 9) методичні рекомендації для вчителів щодо використання даного комплексу.

За характером організаџіï взаємодії учасників навчання розроблені нами ЕНМК поділяються на такі типи:

- інтерактивний - забезпечує дистанційно-консультаційну взаємодію викладача $з$ тим, хто навчається;

- автоматизований програмно-педагогічний засіб навчання - моделює взаємодію викладача з тим, хто навчається, на основі використання автоматизованої 
системи навчання.

Також розрізняємо створені ЕНМК за видами:

- іпермедійний для on-line використання;

- мультимедійний для розміщення на компакт-диску або інших електронних носіях.

Відмінність між видами створених ЕНМК полягає у способі подання теоретичного матеріалу, етапах проходження практичних завдань, використання системи гіперпосилань та завдань для контролю й самоконтролю.

Створення ЕНМК для обдарованих учнів грунтується на дотриманні загальних і специфічних принципів. До загальних відносимо принципи: науковості; наочності; послідовності й наступності; оновлення змісту освіти; гнучкості і прогностичності; системності; комплексності; доступності, різнорівневості навчальних завдань; врахування вікових та індивідуальних особливостей; активності й самостійності навчання; послідовності; міцності, усвідомленості й дієвості знань; оптимізації навчального процесу; ефективності навчання; індивідуалізації й диференціації навчання; варіативності індивідуального досвіду і розвитку індивідуальних освітніх потреб; проблемно-пошукової організації навчання $[4 ; 5 ; 6 ; 8 ; 10]$.

Специфічними принципами створення ЕНМК визначено: моделювання процесів i явищ засобами мультимедійних технологій; зворотного зв'язку; доцільності використання аудіовізуальних засобів, анімації явищ, процесів і ефектів (анімаційних ефектів, аудіоефектів, статичних матеріалів); доповнюваності навчального матеріалу, представленого у підручнику; варіативності форм і змісту навчання, програм, засобів; оперативності, оброблення та систематизації продуктів навчальної діяльності; інтерактивності навчання; урізноманітнення форм подання інформації; самокерованості [4; 5; $6 ; 8 ; 10]$.

У процесі використання ЕНМК реалізуються їхні дидактичні функції, до яких відносимо інформаційну, структурно-систематизуючу, мотиваційно-стимулюючу, інтерактивну і функцію закріплення, контролю і самоконтролю. Інформаційна функція передбачає фіксацію певного обсягу навчального матеріалу як основи навчальної діяльності і формується в суб’єктів освітнього процесу під час роботи з ЕНМК. Ця функція пов'язана 3 педагогічною трансформацією обсягу наукових (теоретичних та емпіричних) знань для висвітлення їх в ЕНМК відповідно до навчальної програми, вікових 
і пізнавальних можливостей учнів. Структурно-систематизуюча функція забезпечує чітку послідовність викладу структурованої навчальної інформації, можливість швидкого пошуку всіх елементів систематизованого навчального матеріалу, поетапність його засвоєння. Функція закріплення, контролю $\boldsymbol{i}$ самоконтролю передбачає можливість самостійної роботи з теоретичним матеріалом, перевірку знань за етапами засвоєння і пов'язана з використанням різних видів контролю: вхідного, поточного, проміжного, підсумкового, вихідного. Мотиваційно-стимулююча функція полягає у розвитку в учнів мотивації та пізнавального інтересу до вивчення навчального предмета $\mathrm{i}$ забезпечується наявністю інтерактивного діалогу «користувач - персональний комп’ютер - тьютор», створенням умов для відкритого навчання за обраною індивідуальною освітньюю траєкторією. Інтерактивна функція відкриває можливість активної взаємодії користувача з інформаційно-освітніми ресурсами ЕНМК. Визначення і фіксація обсягу навчальної інформації забезпечує скорочення нераціональних освітніх траєкторій і часу на вивчення окремих дидактичних модулів, доступність навчання. Наявність зворотного зв'язку дозволяє провести моніторинг дослідження якості засвоєних знань та сформованих умінь і навичок учнів. Можливість неодноразового пояснення різних способів розв'язування завдань має значні переваги порівняно з традиційними засобами навчання. Використання механізму збору матеріалів про рівень підготовки учнів забезпечує формування портфоліо учасників навчально-пізнавальної взаємодії [1; 10].

Управління є однією з важливих умов створення якісних ЕНМК. 3 цією метою сформовано Координаційну раду на базі КОППОПК, до складу якої входять науковопедагогічні, методичні і педагогічні працівники. Координаційна рада є дорадчим органом, який забезпечує управління діяльністю творчих груп зі створення та використання ЕНМК, вирішує питання, пов’язані з використанням ЕНМК у системі очно-дистанційного навчання учнів, а саме: нормативно-правове, організаційно-методичне, науковометодичне, інформаційно-технологічне забезпечення i моніторингове дослідження результативності використання ЕНМК у навчально-виховному процесі. До повноважень Координаційної ради відносяться визначення пріоритетних напрямів діяльності творчих груп і забезпечення координації їх роботи, призначення керівників груп.

До складу Координаційної ради входять: керівник закладу післядипломної педагогічної освіти, заступники 3 навчально-методичної, науково-методичної i 
наукової роботи, працівники центрів дистанційного навчання й IКТ, керівники i члени творчих груп, наукові консультанти.

Очолювати творчу групу може педагогічний працівник, методист або науковець, який має високий рівень професійного розвитку та досвід використання інформаційно-комунікаційних технологій у процесі вивчення навчального предмету. Керівник творчої групи здійснює поточне управління іiі діяльністю зі створення ЕНМК і несе відповідальність перед Координаційною радою за наукову відповідність i зміст створених освітніх продуктів. Науково-методичне забезпечення діяльності педагогічних працівників закладів освіти області зі створення ЕНМК здійснюють відповідні кафедри КОІПОПК, які призначають наукових консультантів із навчальних предметів. Консультування членів творчих груп і питань створення ЕНМК проводиться за їхніми запитами в режимі on-line та off-line.

ЕНМК має такі компоненти змістової складової: методичні рекомендації 3 використання ЕНМК у процесі вивчення навчального предмету і самостійної роботи учнів; характеристику курсу; потижневий розклад і порядок організації навчання; навчальний матеріал (коротка і повна версія занять); робочий зошит; завдання (різнорівневі навчально-пізнавальні, творчі, пошукові, дослідницькі, практичні та лабораторні, практикуми, для проектної діяльності, інтерактивні, системи тестових завдань, для самоконтролю тощо); глосарій; література, інтернет-джерела; зворотний зв язок (е-mail, форум, чат); оцінювання роботи учнів; контроль і моніторинг якості навчання.

Змістова складова ЕНМК (навчальний матеріал) поєднує коротку і повну версії занять. Коротка версія заняття має такі структурні компоненти: розділ (тема); ключові слова; завдання; план розділу (теми); література та Інтернет-ресурси $[4 ; 5 ; 10 ; 12]$. Повна версія заняття детально розкриває зміст даного розділу (теми). Змістова складова ЕНМК має відповідати загальним і специфічним принципам створення ЕНМК і віковим особливостям учнів, яким адресований створений інформаційно-освітній ресурс.

У процесі добору теоретичного матеріалу розробникам важливо дотримуватися таких вимог:

- під час створення гіпермедійного ЕНМК для оп-liпе використання:

- гіпермедійність (перевага гіпертексту і незначна кількість мультимедії);

- педагогічно-орієнтований веб-дизайн; 
- нелінійна структуризація матеріалу;

- візуалізація матеріалу.

- Під час створення мультимедійних ЕНМК:

- послайдова структуризація матеріалу;

- візуалізація за допомогою таблиць, малюнків, графіків тощо;

- озвучування основного і додаткового матеріалу;

- наявність гнучкої системи навігації;

- використання відеозаписів $[4 ; 5 ; 10 ; 12]$.

Інформаційно-технологічні вимоги до створення і використання ЕНМК передбачають: по-перше, використання ліцензованого програмного забезпечення; подруге, оснащення предметного кабінету (центру дистанційного навчання, індивідуального робочого місця) комп'ютером і мультимедійним проектором з екраном або інтерактивною дошкою, навчальним комп'ютерним комплексом, персональним комп'ютером; по-третє, дотримання інформаційно-технологічних вимог до комп ютера, яким користується учень, учитель (IBM сумісний комп`ютер, веббраузер) і до користувача освітніх послуг (володіння комп`ютером на рівні користувача, розуміння принципів роботи веб-браузера, уміння роботи з пошуковими системами) $[4 ; 5 ; 10]$.

Підготовлені ЕНМК подаються розробниками для експертного оцінювання науково-методичною радою КОІПОПК, яка визначає навчальні заклади, наукові лабораторії інституту, на базі яких проводиться апробація комплексу. Наступним етапом $є$ підготовка керівником творчої групи матеріалів для експертного оцінювання ЕНМК науково-методичними комісіями Інституту інноваційних технологій і змісту освіти МОН України.

Важливим етапом впровадження ЕНМК $є$ проведення моніторингових досліджень ïх якості й результативності використання у навчально-виховному процесі, які проводяться центром моніторингу освіти КОІПОПК. Для дослідження розробляється відповідний діагностичний інструментарій, яким передбачено вивчення думки учнів, педагогів, батьків, адміністрації навчальних закладів щодо якості і змісту ЕНМК. Вивчення проводиться за такими критеріями:

- мотивація навчання учнів (активізація навчального процесу, застосування проблемно-пошукових методів навчання, рівень пізнавального інтересу); 
- ерективність процесу навчання (доцільність структуризації навчального матеріалу i пропонованих завдань, зручність його використання, доступність інформації і функціональність запропонованих ресурсів, встановлення зворотного зв'язку, можливість самостійного оволодіння змістом навчального матеріалу);

- результативність навчання (дані про навчальні досягнення учнів, динаміку якісних змін результатів навчання за ЕНМК тощо) [10].

Усі показники оцінюються за 12-бальною шкалою з урахуванням рівнів якості розроблених ЕНМК (високий, достатній, середній, низький). Результати моніторингового дослідження розглядаються науково-методичною радою КОІПОПК, яка формує рішення і пропозиції щодо подальшої організації діяльності творчих груп зі створення нових і вдосконалення існуючих ЕНМК.

На даний час розроблено, апробовано й впроваджено в навчальних закладах системи освіти регіону 20 ЕНМК, зокрема: ЕНМК з курсу «Економічна і соціальна географія світу. 10 клас», «Політична карта світу»; ЕНМК з курсу «Світове господарство»; ЕНМК 3 англійської мови «Test Your English»; ЕНМК із спецкурсу «Історія Франції»; ЕНМК 3 хімії «Портал хімічних знань»; ЕНМК з математики «Планета цілих чисел»; ЕНМК із зарубіжної літератури. 7 клас (дистанційний курс); ЕНМК з основ економіки «Цікава економіка»; ЕНМК 3 курсу «Морфологія»; ЕНМК $з$ курсу «Розв’язування олімпіадних задач $з$ фізики»; ЕНМК 3 курсу «Теорія ймовірностей»; ЕНМК 3 курсу «Історія Української культури»; ЕНМК зі спецкурсу «Вищі безсудинні рослини. Мохоподібні»; ЕНМК з курсу «Я і Україна» для дітей з особливими освітніми потребами; ЕНМК «Геометрія, 7 клас»; ЕНМК «Turbo Pascal 7.0»; ЕНМК «Зарубіжна література. Життя і творчість М. В. Гоголя»; ЕНМК «Математика, 1 клас»; ЕНМК «Я і Україна. Природознавство, 3 клас»; ЕНМК «Географія материків і океанів, 7 клас».

Дані комплекси отримали схвалення науково-методичних комісій Інституту інноваційних технологій і змісту освіти МОН України, рекомендовані до використання в навчально-виховному процесі загальноосвітніх навчальних закладів України і нагороджені золотою медаллю Другої національної виставки «Інноватика в освіті України» (2010), що є свідченням правильності обраного інноваційного поступу творчих педагогів, науковців та методистів системи освіти області й КОІПОПК у створенні сучасного змісту освіти, забезпечення широкого доступу учнів і вчителів до інформаційно-навчальних ресурсів.

\section{Список використаних джерел}


1. Гафурова А., Иванов B., Хачринова О. Структурирование содержания электронного учебника // Высшее образование в России. - 2007. - № 8. - С. 125-127.

2. Гриценко В. І., Кудрявцеева С. П., Колос В. В., Веренич О. В. Дистанційне навчання: теорія та практика: Колективна монографія. - К.: Наукова думка, 2004. $376 \mathrm{c}$.

3. Ермаков Д. С. Электронные курсы для профильного обучения // Педагогика. - 2005. - №2. - С. 36-41.

4. Журавльов А. В., Журавльова И. И. Педагогічно-орієнтований WEB-дизайн для створення електронних навчальних посібників дистанційного навчання [Електронний ресурс] / А. В. Журавльов, И. И. Журавльова // Сборник научных статей конференции «Современные информационные технологии в области культуры и искусства» (22-24.06.2008). - Режим доступу: http://dlab.kiev.ua/konf/10-programmakonferencii-sovremennye-informacionnye.

5. Журавлёва И. И. Модель организации дистанционного обучения: опыт и перспективы [Електронний ресурс] / И. И. Журавльова // Сборник научных статей конференции «Современные информационные технологии в области культуры и искусства» (22-24.06.2008). - Режим доступу: http://dlab.kiev.ua/konf/10-programmakonferencii-sovremennye-informacionnye.

6. Засоби і технології єдиного інформаційного освітнього простору: Зб. наук. праць / За ред. В. Ю. Бикова, Ю. О. Жука / Інститут засобів навчання АПН України. - К.: Атіка, 2004. -240 c.

7. Інформаційне забезпечення навчального процесу: інноваційні засоби і технології: Колективна монографія. - К.: Атіка, 2005. - 252 с.

8. Інформаційні технології і засоби навчання: Зб. наук. праць / За ред. В. Ю. Бикова, Ю. О. Жука / Інститут засобів навчання АПН України. - К.: Атіка, 2005. - 272 c.

9. Клокар Н. І. Положення про електронні навчально-методичні комплекси для обдарованих учнів Київської обласної очно-заочної школи «Інтелектуал». - Біла Церква: КОППОПК, 2011. - 24 с.

10. Клокар Н. І. Концепція створення електронних навчально-методичних комплексів для обдарованих учнів. - Біла Церква: КОІПОПК, 2011. - 18 с.

11. Красовський О. С. Дидактичні основи формування змісту електронних 
підручників // Педагогіка і психологія. - 2008. - № 2(59). - С. 134-142.

12. Кухаренко В. М., Сиротенко Н. Г., Молодих Г. С., Твордохлєбова Н. Є. Дистанційний навчальний процес: Навчальний посібник / За ред. В. Ю. Бикова та В. М. Кухаренка. - К.: Міленіум, 2005. - 292 с.

\section{ОРГАНИЗАЦИОННО-ПЕДАГОГИЧЕСКИЕ ОСНОВЫ СОЗДАНИЯ \\ ЭЛЕКТРОННЫХ УЧЕБНО-МЕТОДИЧЕСКИХ КОМПЛЕКСОВ ДЛЯ УЧАЩИХСЯ}

Клокар Н. И.

Аннотация

В статье отражены дидактичные основы создания электронных учебнометодических комплексов для учащихся. Определены компоненты, характерные признаки, типы электронных учебно-методических комплексов, общие и специфические принципы их создания. Описан полный управленческий цикл создания электронных учебно-методических комплексов для учащихся. Проанализированы компоненты содержательной составляющей, информационнотехнологические требования к созданию и использованию ЭУМК.

Ключевые слова: электронный учебно-методический комплекс для учащихся, информационно-образовательный ресурс, общие и специфические принципы создания ЭУМК, компоненты содержательной составляющей ЭУМК, информационно-технологические требования к созданию и использованию ЭУМК.

\section{ORGANIZATION AND PEDAGOGICAL BASES FOR THE DEVELOPMENT OF ELECTRONIC LEARNING METHODOLOGICAL COMPLEXES FOR PUPILS}

\section{Klokar $N$.}

\section{Resume}

The didactic bases for the development of electronic learning methodological complexes for pupils are described. The components, specific characteristics, types, common and specific principles for the development of electronic learning methodological complexes are determined. Completed management cycle of the development of electronic learning methodological complexes for pupils is described. The components of the content constituent, information and technical requirements for the development and using of ELMC are analyzed. 
Keywords: electronic learning methodological complex, information and educational resource, common and specific principles for the development of ELMC, components of the content constituent of ELMC, information and technical requirements for the development and using of ELMC. 